\title{
Gefarnate increases PAS positive cell density in rabbit conjunctiva
}

\author{
Masatsugu Nakamura, Ken-ichi Endo, Katsuhiko Nakata, Takashi Hamano
}

Nara Research and

Development Center,

Santen

Pharmaceutical Co,

Ltd, Ikoma, Nara,

Japan

M Nakamura

K Endo

K Nakata

Department of

Ophthalmology, Osaka

University School of

Medicine, Suita,

Osaka, Japan

T Hamano

Correspondence to:

Nara Research and

Development Center, Santen

Pharmaceutical Co, Ltd,

Japan.

Accepted for publication 12 May 1998
Masatsugu Nakamura, $\mathrm{PhD}$,

8916-16 Takayama-cho,

Ikoma-shi, Nara, 630-0101,

\begin{abstract}
Aims-The effects of three drugs for the treatment of gastritis and gastric ulcergefarnate, ecabet sodium, and troxipide-on periodic acid Schiff (PAS) positive cell density in rabbit conjunctiva in vivo were investigated.

Methods-Eye drops containing gefarnate $(0.1 \%, 1 \%)$, ecabet sodium $(0.1 \%, 1 \%)$, or troxipide $(0.1 \%, 1 \%)$ were instilled in both eyes of rabbits, six times a day for 7 days. On the eighth day, filter paper was gently pressed on the bulbar and palpebral conjunctiva, and impression cytology was performed with PAS staining. Three points in each specimen were selected randomly, and PAS stained cells were counted.

Results-The instillation of gefarnate increased PAS positive cell density significantly at the concentration of $1 \%$ (p $<0.05$ ). In contrast, instillation of ecabet sodium or troxipide failed to change PAS positive cell density.
\end{abstract}

Conclusions-These results demonstrated that gefarnate stimulates PAS positive cell density in rabbit conjunctiva.

(Br F Ophthalmol 1998;82:1320-1323)

The ocular surface is covered by the tear film, which is composed of a lipid, an aqueous, and a mucous layer. ${ }^{12}$ The mucous layer is innermost and is intimately associated with apical cells of the ocular surface. ${ }^{34}$ The prominent components of the mucous layer are mucins, and the goblet cells in the conjunctiva are classically regarded as the main source of<smiles>CC(C)=CCCC(C)=CCCC(=O)OCC=C(C)CCC=C(C)C</smiles><smiles>CC(C)c1cc2c(cc1S(=O)(=O)O)[C@]1(C)CCC[C@](C)(C(=O)O)[C@@]1(C)CC2</smiles><smiles>COc1cc(C(=O)NC2CCCNC2)cc(OC)c1OC</smiles>

Troxipide these ocular mucins. ${ }^{5}$ The mucins facilitate the spread of tear film over the ocular epithelium by providing a wettable surface for the aqueous layer. ${ }^{67}$ Therefore, the ocular surface mucins play an important role in the protection and maintenance of the ocular surface.

Dry eye is characterised by a decrease in aqueous tear formation and/or a change in the proportions of tear components. ${ }^{12}$ Recently, the number of patients with dry eyes has increased dramatically, but active treatments for dry eye have not been developed. Patients with dry eye resulting from keratoconjunctivitis sicca or Stevens-Johnson syndrome have reduced numbers of goblet cells, ${ }^{89}$ and many laboratory studies have demonstrated a correlation between goblet cell density in conjunctiva and tear film stability on the ocular surface. ${ }^{10-12}$

Eye drops that could stimulate mucin secretion might produce the more stable tear film necessary for the treatment of dry eye. Although the mechanisms of mucin secretion from the goblet cell in conjunctiva are not yet fully understood, some drugs used to treat gastritis and gastric ulcer also stimulate mucous secretion. One of these drugs, gefarnate, has a very low toxicity and no autonomic, anticholinergic, ganglion blocking, or antihistaminic actions. ${ }^{13}{ }^{14}$ Ecabet sodium and troxipide have also been used as anti-ulcer agents and have been shown to stimulate mucous secretion. ${ }^{15-18}$ In this study, we investigated the effects of these three drugs, gefarnate, ecabet sodium, and troxipide, on periodic acid Schiff (PAS) positive cell density in rabbit conjunctiva in vivo.

\section{Materials and methods}

Thirty six albino rabbits (2.0-2.5 kg body weight, Kitayama Labes, Kyoto, Japan) were used. Care and treatment of animals adhered to the Guiding Principles in the Care and Use of Animals (DHEW Publication, NIH 86-23). One group of four rabbits served as an untreated control group. In experiment 1 , we investigated the effect of gefarnate (3,7dimethyl-2,6-octadienyl-5,9,13-trimethyl-4,8, 12-tetradecatrienoate; see Fig 1 for structure; Santen Pharmaceutical Co, Osaka, Japan) on PAS positive cell density in rabbit conjunctiva. Twelve rabbits were divided into three groups (four rabbits, eight eyes per group). The first group received an eye drop vehicle, which contained $0.5 \%$ polysorbate 80 in saline. The second group received $0.1 \%$ gefarnate eye drops, and the third group received $1.0 \%$ gefarnate eye drops. The drops were instilled in both eyes, six times a day for 7 days. 


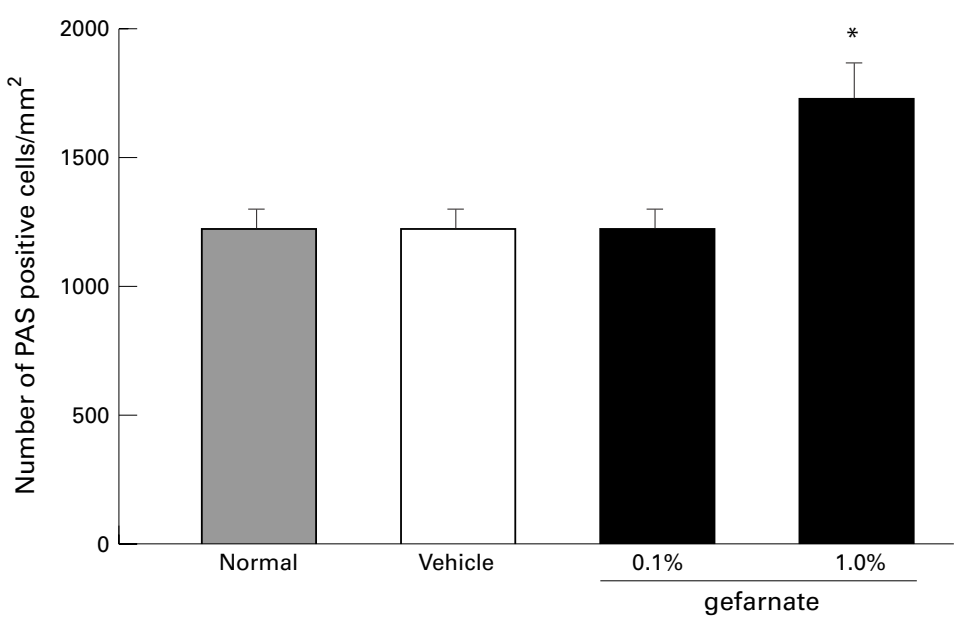

Figure 2 Effect of gefarnate on PAS positive cell density in the temporal superior bulbar conjunctiva. Eye drops (vehicle alone, vehicle with $0.1 \%$ or $1.0 \%$ gefarnate) were instilled in both eyes, six times a day for 7 days. On the eighth day, impression cytology was performed on each eye. There were eight eyes per treatment group. Data are expressed as means (SE). ${ }^{*}$ p value $<0.05$ compared with vehicle group.

In experiment 2 , we investigated the effects of ecabet sodium and troxipide (for their structures; see Fig 1; Santen Pharmaceutical Co, Osaka, Japan). Twenty rabbits were divided into five groups (four rabbits, eight eyes per group). Eye drops were instilled in both eyes, six times a day for 7 days: The first group received an eye drop vehicle, which was phosphate buffered saline (PBS). The second group received $0.1 \%$ ecabet sodium, the third received $1.0 \%$ ecabet sodium, the fourth received $0.1 \%$ troxipide, and the fifth received $1.0 \%$ troxipide. In both experiments, on the eighth day, the animals were anaesthetised with an intravenous injection of pentobarbitone and with oxybuprocaine eye drops. Impression cytology was performed on each eye according to the method of Tseng. ${ }^{9}$ In brief, cellulose acetate filter paper (precut $5 \times 5 \mathrm{~mm}$; Millipore, HAWP 304 F0, Bedford, MA, USA) was placed and gently pressed on each temporal superior bulbar and inferior central palpebral conjunctiva for several seconds. The paper was removed, and the paper with epithelial

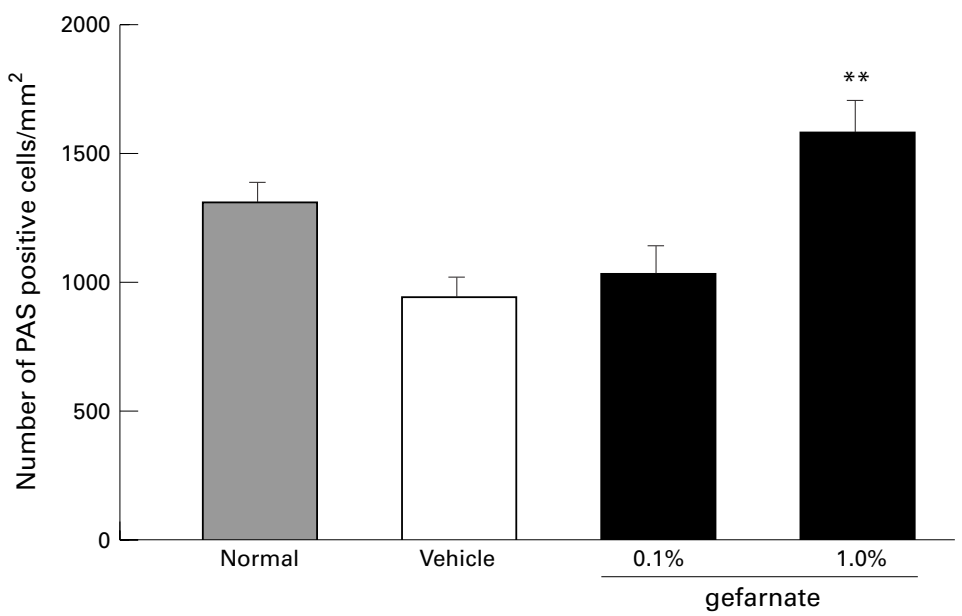

Figure 3 Effect of gefarnate on PAS positive cell density in the inferior central palpebral conjunctiva. Eye drops (vehicle alone, vehicle with $0.1 \%$ or $1.0 \%$ gefarnate) were instilled in both eyes, six times a day for 7 days. On the eighth day, impression cytology was performed on each eye. There were eight eyes per treatment group. Data are expressed as means (SE). ${ }^{\star \star} p<0.01$ compared with vehicle group. cells adhering to it was fixed with a mixture of $37 \%$ formaldehyde, glacial acetic acid, and $70 \%$ ethanol $(1: 1: 20)$. The specimens were stained with periodic acid Schiff reagent (PAS), and PAS positive cells in each specimen were counted under a light microscope (Olympus, BX50, Tokyo, Japan). Although rat conjunctival goblet cells are clustered, ${ }^{19}{ }^{20}$ rabbit and human conjunctival goblet cells are single and not clustered. ${ }^{21}{ }^{22}$ Therefore, three points in each specimen were selected randomly, and the number of PAS positive spots in three $0.2 \mathrm{~mm}^{2}$ areas of each specimen was counted and averaged, and the number of cells per $\mathrm{mm}^{2}$ was calculated. The experiment was carried out in a double masked fashion. Data were expressed as the mean (SE) of eight eyes. The Dunnett multiple comparison test was used for statistical analysis.

\section{Results}

Figure 2 shows the effect of gefarnate on PAS positive cell density in the temporal superior bulbar conjunctiva. The number of PAS positive cells was not significantly different in the untreated control eyes, the eyes treated with vehicle solution alone, and eyes treated with gefarnate at $0.1 \%$. However, eyes in the group treated with $1.0 \%$ gefarnate had significantly more PAS positive cells than eyes in the vehicle group ( $p<0.05)$. Nearly identical results were observed when we examined the effect of gefarnate on PAS positive cell density in the inferior central palpebral conjunctiva. Although $0.1 \%$ gefarnate did not affect the number of PAS positive cells, $1.0 \%$ gefarnate significantly increased their number compared with the vehicle group ( $p<0.01$ ) (Fig 3). Figure 4 shows photomicrographs of the impression cytology results for an eye treated with $1.0 \%$ gefarnate and one treated with vehicle alone in the temporal superior bulbar conjunctiva. Compared with the vehicle group the group treated with $1.0 \%$ gefarnate clearly had more PAS positive cells.

Figure 5 shows the effects of ecabet sodium and troxipide on PAS positive cell density in the temporal superior bulbar conjunctiva. The administration of $0.1 \%$ or $1.0 \%$ ecabet sodium did not change the number of PAS positive cells compared with the number of cells in the PBS treated group. Similarly, neither $0.1 \%$ nor $1.0 \%$ troxipide significantly affected the numbers of PAS positive cells. Nearly identical results were observed when we examined the effects of ecabet sodium and troxipide on PAS positive cell density in the inferior central palpebral conjunctiva. Neither ecabet sodium nor troxipide affected the number of PAS positive cells (data not shown).

\section{Discussion}

The present results, obtained by an impression cytology technique, demonstrate that gefarnate eye drops stimulate the number of PAS positive cells in rabbit conjunctiva in vivo, but that ecabet sodium and troxipide do not. Thus, gefarnate increases PAS positive cell density in conjunctiva. However, the mechanisms of the stimulatory effect of gefarnate on conjunctival 

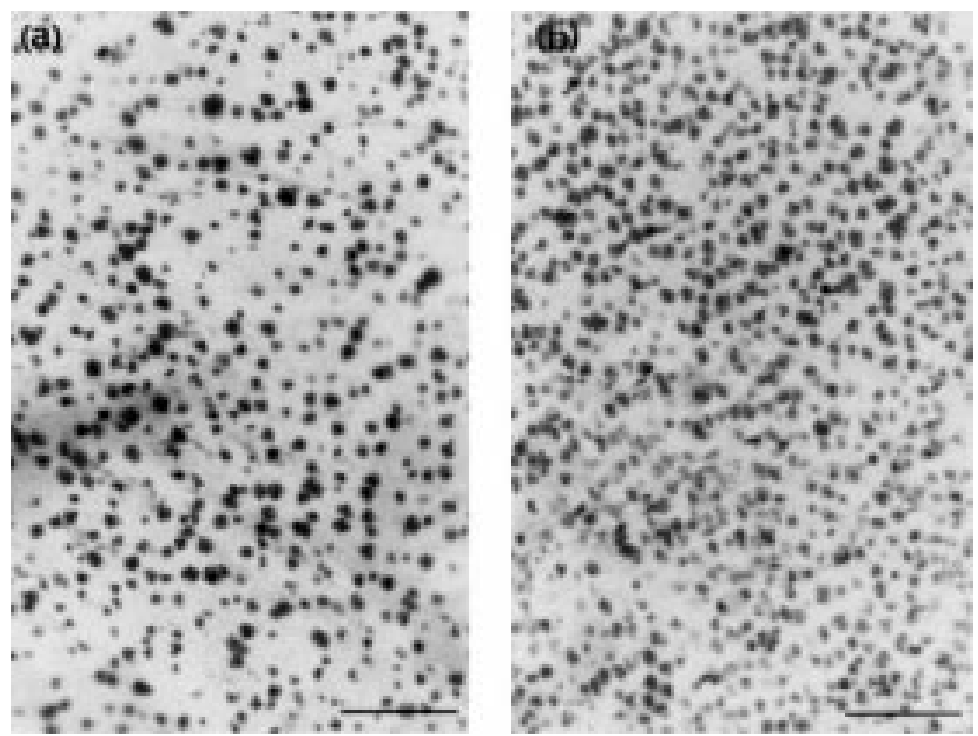

Figure 4 Photomicrographs showing PAS staining of filter paper that was pressed on rabbit bulbar conjunctiva after 7 days of treatment. (a) Vehicle treated group, (b) $1.0 \%$ gefarnate treated group. Bar shows $100 \mu \mathrm{m}$.

PAS positive cell density are not clear. In the present study, both eyes of each animal were treated with gefarnate eye drops. Although we do not know whether gefarnate is absorbed systemically, it is rapidly metabolised in the serum. $^{23}$ Therefore, gefarnate seems to act locally on the conjunctiva.

The size, shape, and density of PAS stained material vary widely. In addition, the number of goblet cells differs among individuals, and the distribution of goblet cells varies over the ocular surface..$^{52}$ To minimise these effects, we counted the number of PAS positive cells, and chose the temporal superior bulbar and the inferior central palpebral conjunctiva, the areas easiest to study with impression cytology. Similar results were obtained when we concomitantly examined the effects of drugs on the number of PAS positive cells in the two areas of each eye. Gefarnate significantly increased the number of PAS positive cells in both areas, but ecabet sodium and troxipide

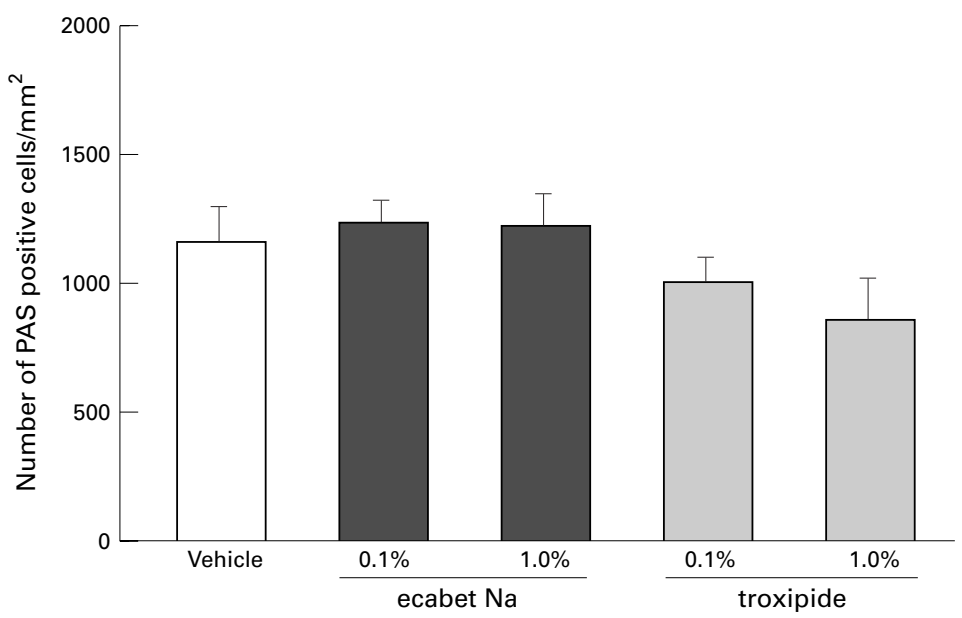

Figure 5 Effects of ecabet sodium and troxipide on PAS positive cell density in the temporal superior bulbar conjunctiva. Eye drops (vehicle, $0.1 \%$ or $1.0 \%$ ecabet sodium, $0.1 \%$ or $1.0 \%$ troxipide) were instilled in both eyes, six times a day for 7 days. On the eighth day, impression cytology was performed on each eye. There were eight eyes per treatment group. Data are expressed as means (SE). had no effect. The number of PAS positive cells counted in each area was in good agreement with those reported by Kishishita and Nakayasu in rabbit conjunctiva. ${ }^{22}$

Studies of the mechanisms of gefarnate's effect on gastritis and gastric ulcer have shown that gefarnate stimulates mucous secretion of hexosamine, acid and neutral mucopolysaccharide and also stimulates the synthesis of prostaglandins (PGs), such as PGE2, PGI2, and PGF2 to protect the mucosal tissues. ${ }^{142425}$ Instillation of the PGE2 analogue, 11-deoxy13,14-didehydro-16-(S)-methylester methyl PGE2, enhanced conjunctival goblet cell mucous secretion in rabbits, ${ }^{26}$ leading to speculation that gefarnate might stimulate PGE2 synthesis in conjunctival epithelium as well as in gastric mucosa. We recently have found that gefarnate stimulated secretion of mucin-like glycoproteins from rat corneal epithelium, ${ }^{27}$ suggesting that similar mechanisms might act on conjunctival goblet cells. However, the increase in PAS positive cell numbers seen with gefarnate might be due to the stimulation of goblet cell synthesis in conjunctiva. More active mucous secretion to the conjunctival surface could have reduced the number of goblet cells on cytological impressions because of depletion of secretion product. Therefore, gefarnate might act on both the stimulation of mucous secretion and goblet cell synthesis in conjunctiva. Further studies on the mechanisms of this stimulatory effect need to the carried out.

Ecabet sodium and troxipide also have been used as anti-ulcer agents, and have been shown to stimulate mucous secretion and PG synthesis to protect the mucosal tissues. ${ }^{15-1828} 29$ In the present studies, however, neither ecabet sodium nor troxipide affected conjunctival goblet cell density, although these agents have the same stimulatory effects as gefarnate on mucous secretion and PG synthesis in gastric mucosa. The different actions of these agents might result from their differing capacity to permeate tissue and/or target specific organs.

The source of ocular surface mucins is classically believed to be the conjunctival goblet cells. However, Gipson et $a l^{30}$ and Watanabe et $a l^{31}$ developed monoclonal antibodies against mucin-like glycoproteins of the rat and human ocular surface. Designated R339 and H185, respectively, these monoclonal antibodies bind to the apical cell membranes of the corneal and conjunctival epithelia, suggesting that corneal and non-goblet conjunctival epithelial cells produce these mucin-like glycoproteins. Recently, expression of the mucins MUC1, MUC4, and MUC5AC were reported in human corneal and conjunctival epithelia. ${ }^{32-34}$ MUC5AC mucin expression was limited to conjunctival goblet cells. Few reports deal with the regulatory mechanisms of MUC5AC mucin expression in conjunctival goblet cells. Further studies are needed to clarify the regulatory mechanisms of MUC5AC expression and the effect of gefarnate on this expression.

Disruption of the tear film leads to deterioration of the ocular surface. Most patients who suffer from mucin deficient dry eye have 
decreased conjunctival goblet cell density, and indeed, many laboratory studies have demonstrated a correlation between goblet cell density in conjunctiva and tear film stability. ${ }^{8-12}$ Furthermore, we recently demonstrated that gefarnate prevented desiccation of the corneal epithelium by stimulating secretion of mucinlike glycoproteins from the corneal epithelium. ${ }^{27}$ Our present results suggest that gefarnate could be used in the treatment of mucin deficient ocular surface disorders.

1 Holly FJ, Lemp MA. Tear physiology and dry eyes. Surv Ophthalmol 1977;22:69-87.

2 Lemp MA. Basic principles and classification of dry eye disorders. In: Lemp MA, Marquardt R, eds. The dry eye. New York: Springer-Verlag, 1992:101-31.

3 Nichols BA, Chiappino ML, Dawson CR. Demonstration of the mucous layer of the tear film by electron microscopy. Invest Ophthalmol Vis Sci 1985;26:464-73.

4 Nichols BA. Conjunctiva. Microsc Res Technique 1996;33: 296-319.

5 Kessing SV. Mucous gland system of the conjunctiva. Acto Ophthalmol 1968;95:9-131.

6 Lemp MA, Holly FJ, Iwata S, et al. The precorneal tear film. I. Factors in spreading and maintaining a continuous tear film over the corneal surface. Arch Ophthalmol 1970;83:89film 94.

7 Holly FJ, Lemp MA. Wettability and wetting of corneal epithelium. Exp Eye Res 1971;11:239-50.

8 Nelson JD, Wright JC. Conjunctival goblet cell densities in ocular surface disease. Arch Ophthalmol 1984;102:1049ocular

9 Tseng SCG. Staging of conjunctival squamous metaplasia by impression cytology. Ophthalmology 1985;92:728-33.

10 Dohlman CH, Friend J, Kalevar V, et al. The glycoprotein (mucus) content of tears from normals and dry eye patients. Exp Eye Res 1976;22:359-65.

11 Kinoshita S, Kiorpes TC, Friend J, et al. Goblet cell density in ocular surface disease. Arch Ophthalmol 1983;101:12847.

12 Tseng SCG, Hirst LW, Maumenee AE, et al. Possible mechanisms for the loss of goblet cells in mucin-deficient disorders. Ophthalmology 1984;91:545-52.

13 Adami E, Marazzi-Uberti E, Turba C. Pharmacological research on gefarnate, a new synthetic isoprenoid with an anti-ulcer action. Arch Int Pharmacodyn 1964;147:113-45.

14 Barbara L, Corinaldesi R, Giorgi-Conciato M, et al. The mechanism of action of gefarnate in the light of the latest data on digestive physiopathology. Curr Med Res Opin data on digestive

15 Abe Y, Sekiguchi H, Tsuru K, et al. Effects of 3,4,5trimethoxy-N-(3-piperidyl) benzamide (KU-54) on the components and glucosamine synthetase of gastric mucosa. Pharmacometrics 1984;27:521-31.

16 Onoda Y, Magaribuchi T, Tamaki H. Effects of 12sulfodehydroabietic acid monosodium salt (TA-2711), a new anti-ulcer agent, on gastric secretion and experimental ulcers in rats. fapan f Pharmacol 1989;51:65-73.
17 Onoda Y, Takido $M$, Magaribuchi $T$, et al. Effects of 12-sulfodehydroabietic acid monosodium salt (TA-2711), a new anti-ulcer agent, on gastric mucosal lesions induced by necrotizing agents and gastric mucosal defensive factors in rats. Fpn F Pharmacol 1990;52:631-8.

18 Momo K, Hoshina K, Ishibashi Y, et al. Preventive effects of troxipide on a newly developed model of acute gastric mucosal lesion (AGML) induced by ischemia/reperfusion plus ammonia in the rat. Folia Pharmacol fpn 1994;104: 313-23.

19 Huang AJW, Tseng SCG, Kenyon KR. Morphogenesis of rat conjunctival goblet cells. Invest Ophthalmol Vis Sci 1988;29:969-975.

20 Kessler TL, Mercer HJ, Zieske JD, et al. Stimulation of gobet cell mucous secretion by activation of nerves in rat conjunctiva. Curr Eye Res 1995;14:985-992.

21 Tseng SCG, Hirst LW, Farazdaghi M, et al. Goblet cell density and vascularization during conjunctival transdifferentiation. Invest Ophthalmol Vis Sci 1984;25:1168-1176.

22 Kishishita H, Nakayasu K. Distribution of conjunctival goblet cells and observation of goblet cells after conjunctival autotransplantation in rabbits. $\mathcal{F}$ fpn Ophthalmol Soc 1996; 100:433-42.

23 Coppi G, Bonard G, Martinelli E. On the metabolic fate of gefarnate in rats. Arzneim Forsch 1969;19:1519-20.

24 Takagi K, Yano S. Effect of anti-ulcer drugs on gastric mucous hexosamine in rats subjected to several ulcerogenic conditions. Chem Pharm Bull 1972;20:1170-4.

25 Arakawa T, Nakamura H, Satoh H, et al. Prostaglandins in the rat gastric mucosa. Jpn f Gastroenterol 1982;79:1898903.

26 Aragona P, Candela V, Caputi AP, et al. Effects of a stable analogue of PGE2 (11-deoxy-13,14-didehydro-16 (S)methylester methyl PGE2: FGE 20700) on the secretory processes of conjunctival goblet cells of rabbit. Exp Eye Res 1987;45:647-54.

27 Nakamura M, Endo K, Nakata K, et al. Gefarnate stimulates secretion of mucin-like glycoproteins by corneal epithelium in vitro and protects corneal epithelium from desiccation in vivo. Exp Eye Res 1997;65:569-74.

28 Kinoshita M, Kume E, Tamaki H. Roles of prostaglandins, nitric oxide and the capsaicin-sensitive sensory nerves in gastroprotection produced by ecabet sodium. 7 Pharmacol Exp Ther 1995;275:494-501.

29 Mochizuki T, Sekiguchi H, Hamada K, et al. Effects of 3,4,5-trimethoxy-N-3-piperidylbenzamide (troxipide), an anti-ulcer agent, on gastric mucosal prostaglandins. Pharmacometrics 1986;32:387-95.

30 Gipson IK, Yankauckas M, Spurr-Michaud SJ, et al. Characteristics of a glycoprotein in the ocular surface glycocalyx. Invest Ophthalmol Vis Sci 1992;33:218-27.

31 Watanabe H, Fabricant M, Tisdale AS, et al. Human corneal and conjunctival epithelia produce a mucin-like glycoprotein for the apical surface. Invest Ophthalmol Vis $\mathrm{Sci}$ 1995;36:337-44

32 Inatomi T, Spurr-Michaud S, Tisdale AS, et al. Human corneal and conjunctival epithelia express MUC1 mucin. Invest Ophthalmol Vis Sci 1995;36:1818-27.

33 Inatomi T, Spurr-Michaud S, Tisdale AS, et al. Expression of secretory mucin genes by human conjunctival epithelia. Invest Ophthalmol Vis Sci 1996;37:1684-92.

34 Gipson IK, Inatomi T. Mucin genes expressed by the ocular surface epithelium. Prog Retinal Eye Res 1997;16:81-98. 